\title{
Medium-scale commercial farms in Africa: the experience of the 'native purchase areas' in Zimbabwe
}

\author{
Ian Scoones, Blasio Mavedzenge and Felix Murimbarimba
}

\section{Introduction}

Debates about the role of medium-scale commercial farms in African agriculture have returned recently, with analyses of changing farm size distribution across the continent (Jayne et al. 2014; 2016; Sitko and Jayne 2014; Anseeuw et al. 2016). This is not a new phenomenon. Attempts to generate a class of 'emergent', 'yeoman' farmers preoccupied colonial administrations and post-independence governments alike (Wolmer and Scoones 2000). A linear, technocratic, modernization vision of agricultural commercialization was often promoted, envisioning structural transformation of the agricultural sector, led by a new technically proficient and educated farming class (Bernstein 1998). However, as Sara Berry (1993) has shown for historical cases across Africa, commercialization processes are not linear or predictable, but are influenced by interlocking conjunctures of social dynamics, generational changes and political-economic conditions. Pathways of commercialization are diverse and contingent, dependent on intersecting socialrelational and structural processes.

This article explores the experience from the 1930s of the 'native purchase areas' (NPAs) - now known as small-scale commercial farming areas (SSCFAs) - in Zimbabwe, reflecting on Berry's analysis. We ask whether the experience of the NPAs provides potential insights into what might happen in the future to new medium-scale farms being established across Africa, and in Zimbabwe following land reform in 2000. NPAs were seen as a route to allowing educated, relatively elite Africans to purchase land under freehold title, and to generating a 'yeoman class' of farmer. NPAs were further extended in the 1950s as a political response to growing nationalist activity, again linked to a technocratic vision of 'civilized', good farming aimed at commercial production (Shutt 1997).

This experience has contemporary echoes. There is much policy hype today about the potential for such medium-scale commercial farms across Africa. They are supposed to be the new drivers of growth in rural areas, where new capital and expertise are deployed to modernize agriculture and increase its market reach (Morris et al. 2009). By enlisting well-connected business and political actors in a drive towards sustained agricultural growth, such medium-scale

\footnotetext{
Ian Scoones is a Professorial Fellow at the Institute of Development Studies at the University of Sussex, and Director of the ESRC STEPS Centre. Email: I.Scoones@ids.ac.uk

Blasio Mavedzenge (sadly now deceased) and Felix Murimbarimba previously worked as agricultural extension workers in Masvingo Province. Together with Ian Scoones, they were co-authors of the book Zimbabwe's Land Reform: myths and realities (James Currey, 2010), and they worked together on land and agrarian change questions in rural Zimbabwe since the late 1980s.
} 
enterprises are seen as an alternative to large-scale corporate 'land grabbing' (Jayne et al. 2014) and small-scale peasant farming (Collier and Dercon 2014).

In Ghana and Zambia, for example, such medium-scale farms now account for more land area than small-scale farms (under 5 hectares) (Jayne et al. 2016). Land concentration in such farms, under new ownership and land tenure arrangements, occurs through different routes - either through accumulation of land by those who previously had smaller plots via local land markets, or through the acquisition of land by 'outsiders' via political and other connections. Jayne et al. (2016: 197) claim that:

Medium-scale farms control roughly $20 \%$ of total farmland in Kenya, $32 \%$ in Ghana, $39 \%$ in Tanzania, and over 50\% in Zambia ... the rapid rise of medium-scale holdings in most cases reflects increased interest in land by urban-based professionals or influential rural people. About half of these farmers obtained their land later in life, financed by nonfarm income.

In Zimbabwe, the major land reform of 2000 created over 20,000 medium-scale farms (designated A2). These now cover approximately 2.7 million hectares, with an average size of 134 hectares (Moyo 2011: 512). A2 farms emerged as part of a political bargain, allowing those in salaried jobs or in private business, or those recently retired, often from government service, to benefit from the land reform alongside smallholders on A1 land reform schemes (Moyo and Chambati 2013). A2 applicants were supposed to produce a clear business plan for farming and show commitment, skills and capital to invest, although opportunities for corruption and patronage were rife (Scoones et al. 2010). As a result, there are many more people in rural areas with connections and political clout who have invested in agricultural production, at least on a part-time basis (Scoones 2015).

Could medium-scale farming be the bright new future for commercial agriculture in Zimbabwe and across Africa, as some claim? What are the dynamics of investment, and how can often part-time, urban-based farmers succeed? How will land and resources transfer across generations, and how will competing claims on farms be resolved? Will such farms inevitably evolve towards a commercial production ideal, or will other trajectories be observed?

\section{The native purchase areas: a window into the future?}

One way of informing this enquiry is to look at past experiences. Today, the SSCFAs add up to 1.4 million hectares in total, across approximately 8,000 farms. As with the A2 farms, they accommodated an educated, urban-based middle class, often with jobs with the state. As with the land reform of 2000, there were explicit political motivations to enlist and incorporate members of this class, but also a production-focused modernization agenda to generate new forms of commercial agriculture.

The NPA policy narrative was clearly focused on a 'civilizing' mission - these were acceptable, English-speaking 'natives', educated through the mission school systems, and valued clerks, messengers, native police, teachers and others working for the colonial state (Shutt 1997). Politically, the colonial regime could not afford 
for such groups to rebel and join the ranks of the nationalists (although, of course, many did), and needed them to be co-opted by being given special favours notably freehold title to land - that were not available to the 'reserve native' (Shutt 2002a). Others given land were those Africans who neither had land in the 'reserves' nor were acceptable in 'white' areas, and included South African Basotho migrants, members of African churches and others (Mujere 2014). The allocations of land varied from area to area, but they were of the order of 100 hectares - not dissimilar to those offered to most A2 farmers in the 2000s.

What, then, has happened to the former NPAs eighty years and several generations on? Do these experiences give hints as to what might happen to the A2 farms in the future? What lessons can be drawn? We have focused our studies on Mushagashe SSCFA, about 35 kilometres north of Masvingo. Acquired by the colonial state in the early 1930s, it is 26,800 hectares in extent and contains 255 allocated farms. It is a dryland area, with an average of 662 millimetres of rainfall recorded per annum in nearby Masvingo over the period 2000-01 to 2016-17. ${ }^{1}$ While most farms have poor sandy soils or loams, there are patches of wetland with heavier soil. In terms of areas cultivated in 2015-16, maize was the major crop (68 per cent of the cropped area), followed by groundnuts (11 per cent), finger millet (10 per cent), Bambara nuts ( 8 per cent), cowpeas ( 2 per cent) and sugar beans ( 1 per cent). A very small amount of rice is grown in the wetland patches. The total cattle population is around 3,500, with approximately 250 owners. $^{2}$

The area is designated 'Region IV' in the national classification, implying its marginality for cropping, and many current residents commented on poor soils and frequent droughts. For example, one observed, 'Rainfall is also very low these years and crops are affected by drought. Our soils are now poor due to continued use.' Another said, 'The problems we are now facing are low rainfall and lack of resources - this is because of continuous drought we are encountering in recent years.' While the granite-derived sandy/loam soils of this region are depleted and deficient in soil nutrients (Mapfumo et al. 2007), long-term rainfall data do not show a secular decline but rather a pattern of increased variability (Makuvaro et al. 2017).

We randomly sampled twenty-six farms across Mushagashe West and North to encompass a range of agro-ecologies, and we conducted a survey of each farm, exploring current production and investment patterns, as well as a cross-generational analysis of livelihoods of all children of the current farm owners $(n=$ 109). To complement the more quantitative assessments, we investigated detailed farm histories of all sampled farms, including life histories of older household members, both men and women. ${ }^{3}$

We were especially interested in patterns of change over time and the social dynamics of agrarian change across generations (Berry 1993).

\footnotetext{
${ }^{1}$ The coefficient of variation is 29 per cent, maximum 982 millimetres, minimum 290 millimetres, and five of the seventeen years had rainfall levels more than 20 per cent below the mean, indicating a high frequency of drought.

${ }^{2}$ Data from the local Ministry of Agriculture, Agritex office, 2016.

${ }^{3}$ The survey and interviews were undertaken from April to November 2016. All quotes in the article are derived from the historical interviews with the twenty-six sampled households.
} 
Commercialization outcomes are dependent on the intersection of relational dynamics (Berry 1989) and more structural, political economy features (Peters 2004). We thus traced relationships between demographic and accumulation cycles in the peasant economy (van der Ploeg 2013), patterns of circular migration (Potts 2010), farmers' identities (Cousins and Scoones 2010), and the gendered dimensions of life courses (Dancer and Tsikata 2015). By tracing farm histories, we looked at how patterns of accumulation linked to the farm were financed, and what 'commercial' farm production meant in practice. The role of freehold title as a means to raise finance was also explored (Boone 2007), as well as the influence of structural features of state policy on the opportunities for accumulation (Poulton et al. 2006). Through a cross-generational analysis, we explored how inheritance or subdivision and the sharing of land were addressed, as well as examining the lives of children of farm owners (White 2012).

There has been remarkably little attention paid to the former NPAs in recent scholarship, and this study aims to fill a gap. The classic studies by Cheater in Musengezi near Harare $(1982 ; 1984)$ are now over thirty-five years old. More recently, important historical work has been published, but this has not engaged fully with more recent developments (Shutt 1997; 2000; 2002a). Mujere (2014) undertook a fascinating study of the Basotho settlers in Dewure, also in Masvingo, but this concentrated on a particular group, not the wider area. A single survey by Ashworth (1994), meanwhile, offered a snapshot of conditions in the SSCFAs twenty-five years ago.

The NPAs, we argue, offer important insights for contemporary debates. Taking inspiration from Berry's earlier work in particular, our aim has been to look at the intersection of social relations and structural constraints influencing agrarian change, exploring the range of factors affecting processes of agricultural commercialization. As well as periods of success, we were also interested in processes of decline and even abandonment of farms. By investigating the dynamics of accumulation, investment, class formation and gender differentiation in Mushagashe, the aim has been to inform the wider debate about the future of medium-scale commercial farming in Africa.

\section{A brief history of Zimbabwe's small-scale commercial farming areas}

The NPAs were established as a result of the 1930 Land Apportionment Act, following the recommendations of the 1925 Morris Carter Commission (Cheater 1984). They were designed as compensation for the fact that, because land was divided between 'native' and 'European' use, Africans were not allowed to purchase land elsewhere. These were areas that had mostly been farmed by early settlers before the colony's land was carved up into racial designations. Africans were given the option of buying newly demarcated properties, but the land was often in remote areas and of poor quality (Palmer 1977; Phimister 1988; Cheater 1984; Shutt 1997).

The NPAs were slow to become established. At independence in 1980, around 10,000 households had settled on around 1.4 million hectares, falling far short of the earlier promises of 50,000 Africans with freehold title (Shutt 1997; 2002a). The vast majority of the acquisitions were by men, although some women did manage 
to buy independently (Cheater 1981). Initially, those living in the 'native reserves' were reluctant to move, as the successful 'reserve entrepreneurs' (cf. Ranger 1995) had land, labour and markets where they already lived. Urban-based Africans, especially government workers, were also encouraged to sign up, but again many felt that the leap into the unknown was too risky, as, after all, they already had rural homes in the 'reserves'. The depression of the 1930s put the squeeze on incomes, and few had the money or cattle to purchase land.

In the 1930s and 1940s, farming of wetland patches was important. One informant recalled:

My father grew maize, groundnuts, Bambara nuts, finger millet, wheat, rice and yams in wetlands, often inter-cropping. There was a lot of rainfall during that time. He produced enough crops for household use and some excess for sale. He exchanged groundnuts and wheat for clothes and grocery items with a white businessman nicknamed muGreek.

In interviews, the difficulties of establishing agriculture were stressed. For example:

When K. M. came to the farm in the 1930 s he had plenty of cattle and goats. He sold some locally or to the market in Zimuto communal area. He also grew crops such as maize, groundnuts, finger millet, wheat, Bambara nuts and a bit of rice. There were good rains at the time and the harvest was fair. He planted up to 10 hectares. Crops were sold to people in exchange for goods and money. The problems they faced included unreliable markets and wild animals, especially spring hares.

Households accumulated assets, notably cattle, over time, and labour was plentiful given the large polygamous families of that generation. One informant recalled:

When my grandfather came here [in the early 1930s] he had hundreds of cattle and three wives. He had many children so therefore the labour force was plentiful. Because of good rainfall, he grew very big areas of crops such as maize, rapoko [finger millet], groundnuts, rice and lots of winter wheat.

In our sample, around half of the farms were acquired before 1940, mostly during the early 1930s, while just over a quarter were acquired during the 1940s, and a further fifth during the 1950s. Most were paid for in instalments, while some were paid outright with cash or cattle. Acquisition was conditional on the following of certain practices. For example:

This farm was bought from the government in about 1930. The first instalment was $£ 30$. The farm would become yours after you had been able to implement certain practices, such as digging of contour ridges. The number of cattle required at the farm was not allowed to exceed the farm carrying capacity. Those who owned many cattle and did not want to destock were evicted from the farms.

As noted in this recollection, accumulation of cattle was limited by the imposition of carrying capacity limits, and by destocking in the 1930s (Shutt 2002b) and again in the 1950s (Phimister 1988). Another current resident remembered this period: 'My father had many cattle when he settled here [in 1942], but these were reduced under orders from government to comply with the cattle carrying capacity 
of his farm.' Some were evicted for non-compliance in relation to stocking rates and the digging of contour ridges: 'At that time [1940s], if one did not meet the required standards of farming, you were evicted,' said another informant.

By the 1940s, the NPAs were often criticized for being poor, backward, wasteful and inefficient. Rather than intensified production, the main trends were extensification of low productivity, mixed farms, opportunistic use of wetlands and resource extraction of wood for timber and fuel (Shutt 2002a). Many NPA landowners were 'absentee farmers', and, according to officials, were not taking care of their properties. They accumulated, but not in ways that the planners had hoped. The commentary on both production efficiency and environmental degradation was damning. These were not the envisaged modern, commercial farming areas; instead, they were often the second homes of urban, employed Africans, for whom farming was a sideline. Today, the 'cell-phone farmers' of the A2 resettlements are cast in a similar light.

After World War Two, more people acquired farms as the colonial authorities offered opportunities to educated Africans (West 2002). The earlier reticence gave way to an enthusiasm for social and economic transformation. As Ranger's (1995) biography of the Samkange family shows, the purchase of their Musengezi farm was a key moment in the family's history, shifting their identity as an educated African middle class, now straddling urban and rural areas. As Shutt (1997: 556-7) put it: '[T]he Purchase Areas offered privacy, a measure of respect from the colonial government, and a symbolic separateness from African cultivators in the reserves and from lower-paid workers.' As one of our informants recalled: 'I wanted a home that was independent.' This independence was reinforced in the 1950s when, following the Native Land Husbandry Act of 1951, freehold title was offered. Freehold was seen as the ultimate form of ownership, linked to a certain modernization ideology and pattern of accumulation (Cheater 1984) that were otherwise available only to whites.

From the mid-1950s, those who had earlier acquired farms began retiring. This was a moment when more commercialization took place. The areas were now fully occupied and land extensification and high stocking rates were no longer feasible. Tobacco and cotton became favoured crops, linked to new commercial value chains. From the 1950s, 'squatters' were considered a problem by the authorities, but farmers were grateful for additional supplies of labour (Shutt 1997). In Mushagashe, labour was hired from nearby communal areas and Makoholi research station, while 'squatters', many of whom were relatives of the farm owners with small plots of land, also provided labour. The labour regime changed from one based on family labour in large polygamous households to hired labour, complemented by collective work parties. The shortage of labour is a commonly cited constraint today. An informant recalled his father's time: 'He always worked with neighbours in work parties for weeding and carrying of manure. He also had many children and relatives who were staying with him, meaning there was always enough labour.' This contrasts with a contemporary complaint from an ageing couple: 'Now we are old and there is a labour and manure shortage; we are now failing to grow crops on large areas. Work parties come to our rescue especially when carrying manure.' Others complained about the decline in collective work: 'I am reducing the cropping land because of labour shortages. Neighbours are no longer interested in work parties; most of 
the youth in the area have gone to towns for work and others do not like to work on farms.'

In the 1950s, for the first time freehold titles acquired more than symbolic value, and loans were offered against titles as collateral (Shutt 2002a). Farms were more assertively demarcated, with fences put up to keep out neighbours from the reserves. The state invested more effort in these areas, improving infrastructure, providing finance and offering technical support. As the threat of growing nationalism became apparent, especially among the educated African elite, these areas became a focus for political and administrative attention after years of neglect (Cheater 1984).

Together with title deeds came a period of land sales and fragmentation of farms, as plots were sold off. This provided important revenues for some, securing their retirement on smaller farms. Five of our sample farms were acquired as a result of subdivision, often with different brothers acquiring parcels together. Also, with increasing intensification of production there came the need for more labour. Those designated as 'squatters' were crucial. As Cheater (1982) describes for Musengezi, these included a wide range of people, including extended family members, peasants from the reserves, migrant labourers and others. The subdivision of land also meant that relatives - usually sons - could inherit land, and a new generation took ownership. Land rentals also increased, as demand grew for land - including from 'squatters'. Within increasing fragmentation, officials complained that the NPAs were becoming just like the reserves (Shutt 1997). However, despite these admonishments, the mid- to late 1950s and early 1960s saw a brief period of prosperity in the NPAs. Land sales and rentals, some cash crop production, continued resource extraction and plentiful cheap labour ensured that farming generated decent returns for the now resident, retired owners of these farms.

By the mid-1960s, and especially with the Unilateral Declaration of Independence in 1965, this changed again. Shifts in the political climate, which intensified during the liberation war, saw a decline in state support. The NPAs were often seen with suspicion as places of nationalist organizing and dissent (Ranger 1985). With independence in 1980, nothing much changed. The SSCFAs, as they were now called, were seen as an anomaly of the colonial era, and the state's efforts were focused elsewhere.

By the mid-1970s, ${ }^{4}$ Mushagashe had expanded to 249 farms, with an average size of 98 hectares, although only 7.2 hectares were cultivated on average. In the period between 1974 and 1977, maize output averaged 4.4 tonnes per household, with an average of 1.7 tonnes being sold. Households held 22.5 cattle on average, and sold 2.2 animals per year. Around a third of farmers had permanent workers with 1.7 per farm on average - in addition to substantial casual labour hired by all farmers. There was also significant family labour, with on average thirteen people being resident (and most available to work) on each farm. Intensification was limited, with only five tractors recorded across all farms, and fertilizer inputs were relatively modest.

\footnotetext{
${ }^{4}$ Data derived from Central Statistics Office annual reports on purchase areas, which were produced for the years 1973-74, 1975-76 and 1976-77 (only average figures are presented).
} 
In sum, over the last eighty years, the former NPAs have seen mixed fortunes. Bursts of commercialization, notably of cotton and tobacco production, have been combined with periods of decline. Generational changes have influenced patterns of accumulation, land subdivision and labour demand, while the shifting focus of state policy has seen varying levels of attention being paid to farms. Far from being linear, the process of change has instead been one influenced by contingent factors and the intersection of socialrelational and structural political-economic dynamics, much as Berry (1993) has noted elsewhere in Africa.

\section{Making a livelihood in Mushagashe}

How do we explain the changes in our study site of Mushagashe SSCFA over the last eighty years? This section offers an overview of how different farmers make a living in the area, and the problems they have faced.

Rankings of current challenges put 'drought' as number one, followed by 'poor soil fertility', 'family disputes' (mostly over ownership or title), 'absentee sons not investing', 'wildlife destroying crops', 'lack of government support' (for finance or loans, roads, irrigation, dipping, etc.), and 'theft by communal area people'. As discussed earlier, inter-annual variation in rainfall appears to be increasing, even if overall rainfall is not declining. Perceptions of 'drought' therefore are heightened, as low rainfall years are more frequent, even if they are interspersed with higher rainfall periods.

These challenges are not static, however, and will change within a household over time. Some changes emerge as part of a demographic cycle, while others are the result of a sudden event, with consequences that are either negative (such as deaths or illnesses in the family or significant cattle mortality due to disease or drought) or positive (for example, a pension or redundancy payout or an unexpected inheritance). One informant offered a picture of such change:

The original owner of our 92 hectare farm was a pastor, and he came to Mushagashe with fifty cattle and many goats. He grew maize, groundnuts and finger millet. His arable lands were around 10 hectares. He practised shifting cultivation. He also used leaf litter humus and kraal manure to add fertility to his lands. He was a respected farmer who had farming knowledge, and local farmers used to come and consult him. At present we are cultivating only 3 to 4 hectares between us. We no longer grow large areas because of labour shortages. We do keep livestock and have twenty-nine cattle on the farm owned by the two households that stay on the farm. We hope our sons will help revive the farm again.

All our biographical interviews, like this one, offer a vivid sense of cyclically changing fortunes over time - from periods of success, generating investment and accumulation, to periods of decline, and back again, with hopes pinned on a new generation.

The following sections explore the Mushagashe farms in more depth, starting with a basic overview of the farms and their inhabitants. 


\section{Farm profiles}

Table 1 offers a profile of current farms and household heads, showing an ageing, well-educated group, strongly linked to the Catholic Church, and with professional and business backgrounds. All but two were men. Average farm sizes have not changed significantly over time, but there is now a significant range observed, reflecting subdivisions and accumulation through purchasing or inheriting new land. With nearly three-quarters of households born on the farm, a pattern of multi-generational transfer of farm holdings is seen, reflected in turn by the presence of children's homes and plots on farms.

Unlike in the past, polygamy is absent, and multiple marriages are no longer seen as 'idioms of accumulation' (Cheater 1984), a route to mobilizing large labour forces for on-farm production. Mission education through the Catholic Church has had a significant influence. In accounts of their lives, household heads saw education in particular, funded by agriculture, as a route to getting a job and for longer-term success. For example: 'We sold cattle to the whites who had farms near here. Our education came from farming. I was born in 1938, and I boarded at Gokomere to Standard 6 aged seventeen. I then worked as a policeman in Zambia during the Federation, coming back here in 1972.' Educational attainment of household heads was significant, but their children have had even more schooling, with all children educated at least to secondary school and many to university/college level.

Many household heads had worked in public service jobs in the pre-independence era. This included various civil service roles and a range of 'security' jobs, including police, prison officers and soldiers (Table 1). Younger household heads had worked in business for a company, while some had been farmers all their lives or were self-employed. This pattern mirrors the class profile of A2 farmers, with many being employed by the state, including in the security services,

\section{TABLE 1}

Farm and household head profiles

\begin{tabular}{lll}
\hline \hline Category & Criterion & Number/percentage \\
\hline Farm size & Average & 109 ha \\
Age & Range & $63-250$ ha \\
& Over 60 years & $63 \%$ \\
Education & Over 50 years & $75 \%$ \\
\multirow{2}{*}{ Children } & Completed primary & $54 \%$ \\
\multirow{5}{*}{ Previous occupation } & Completed secondary & $46 \%$ \\
& Average number & 5.3 \\
& Farms with children's homes/plots & $27 \%$ \\
& Farmer & $15 \%$ \\
& Civil servant & $15 \%$ \\
Church affiliation & Security services & $27 \%$ \\
& Self-employed business & $8 \%$ \\
& Work in a company & $35 \%$ \\
& Catholic & $65 \%$ \\
& Reformed Church of Zimbabwe & $23 \%$ \\
& Other (mostly evangelical) & $12 \%$
\end{tabular}


and as teachers and in other professions. A prominent role for businessmen, often with political connections, is also noted (Scoones et al. 2010). Profiles of mediumscale farmers elsewhere in Africa are similar, with a predominance of former government workers and urban-based business people (Jayne et al. 2016).

\section{Farm production}

Table 2 offers an overview of farm production across our sample farms. The small land areas cultivated, limited mechanization and small number of workers hired indicate, on average, a low level of commercialization, although there are important variations.

The relatively high numbers of cattle ease tillage constraints, with nearly everyone owning sufficient cattle to put together a span. In addition goats, sheep and donkeys are held, alongside indigenous chickens, while some have broiler projects (Table 2). Cattle are sold regularly, and a few households are involved in milk production, with milk sold to the nearby cooperative, with a maximum of 180 litres being sold per month.

Maize is the dominant crop. Total output averaged 3.5 tonnes between the 2013 and 2015 seasons, with large ranges but regular sales by most households (Table 2). Other crops grown include groundnuts and nyimo (Bambara nuts). All households have a vegetable garden, but only two have pump irrigation for commercial production of green maize and horticultural products. Some have access to dambo (wetland) gardens but, as many commented, these are not as well watered or productive as they once were, and only two households in our sample grew rice. 'The wetlands have now dried up. We used to grow rice and yams there, and there were always two crops a year on these patches,' one informant commented.

\section{TABLE 2}

Farm production

\begin{tabular}{lll}
\hline \hline Category & Criterion & Number/percentage (range) \\
\hline Cultivated land & Area & 4.7 ha $(2.0-9.0$ ha) \\
Livestock & Cattle owned & $22.8(7-57)$ \\
& Cattle held for others & $0.8(0-11)$ \\
& Cattle sales last year & $1.4(0-8)$ \\
& Dairy operations & $11.5 \%$ \\
& Goats owned & $6.1(0-28)$ \\
& Sheep owned & $0.8(0-7)$ \\
Cropping & Donkeys owned & $0.4(0-4)$ \\
& Maize production $(2015)$ & 2.7 tonnes $(0.0-7.0$ tonnes) \\
Tillage & Maize production (2014) & 4.5 tonnes $(0.5-12.0$ tonnes) \\
& Maize production (2013) & $3.4(0.2-9.0$ tonnes) \\
Hired labour & Ox ploughing & $100 \%$ \\
& Communal work parties & $35 \%$ \\
& Tractor ownership & $7.7 \%$ \\
& Numbers hired & $1.4(0-4)$ \\
& Worker days per year & $17.4(0-90)$ \\
\hline
\end{tabular}




\section{Diversified livelihoods}

Farm production is combined with other sources of income in a diversified portfolio. Connections to urban areas are important for many, as are remittances from children and others. Table 3 shows the activities identified in the top three income sources across the sample.

Only one household did not identify farming as one of its top three income sources, as it relied on a mix of house rental, remittance and pension income. Fifty-eight per cent identified farming as their main source of income, while 35 per cent identified ongoing employment, and 4 per cent pensions. Regular cash remittances from relatives were important for some, combined with in-kind support, such as the supply of groceries, or investments on the farm. Income earning was highly gendered, with women emphasizing beer brewing and vegetable sales.

In addition to houses built on the farm (some quite elaborate, and all with solar electricity and many with water pumps), farm households had invested in various forms of transport. ${ }^{5}$ However, compared with nearby resettlement areas or even communal areas, this level of asset ownership was not significantly higher, ${ }^{6}$ indicating limited accumulation in recent years as farm owners aged. Most pointed to remittance, pension or employment income as the source of financing, rather than the farm itself.

\section{Inheritance and property}

Many household heads are now old, and inheritance by the next generation is an issue. A range of patterns is observed, with wives, brothers and sons inheriting, but

\section{TABLE 3}

Income sources

Income source

Percentage of households naming the activity

Farming in their top three income sources

Fmplom $36 \%$

Employment off-farm $\quad 35 \%$

$\begin{array}{ll}\text { Beer mions } & 35 \% \\ \text { Part-ime } & 30 \%\end{array}$

Part-time piecework $15 \%$

House rentals in town $\quad 8 \%$

Grinding mill income $\quad 8 \%$

\footnotetext{
${ }^{5}$ On average, households had 0.4 trucks (range: zero to two), 0.5 cars (range: zero to four) and 1.3 bicycles (range: zero to six).

"See: 'How have the "new farmers" fared? An update on the Masvingo study IV', Zimbabweland blog, 21 April $2014<$ https://zimbabweland.wordpress.com/2014/04/21/1049/>; 'Comparing communal areas and new resettlements in Zimbabwe IV: accumulating assets and investing in the land', Zimbabweland blog, 28 July $2014<$ https://zimbabweland.wordpress.com/ 2014/07/28/comparing-communal-areas-and-new-resettlements-in-zimbabwe-iv-accumulatingassets-and-investing-in-the-land/>, both accessed 6 April 2017.
} 
often with significant internal family wrangles. For example, an informant commented:

The farm was given to me through a will that my father wrote saying I be given the farm after his death. Today there are some squabbles about the inheritance issues. The older brother has taken the issue to the chief's court. I have gone to the chief's court nearly every week!

Social dynamics across generations and within families are central, as farming and processes of accumulation are deeply embedded in particular social relations. In the above case, due to ageing and a lack of labour, there was currently a reliance on cattle rather than cropping. But this may change again. Inheritance issues are at the core of these dynamics, as farms are usually passed between male kin, but not without disputes. Across our sample, there were three cases where inheritance disputes had emerged. In some cases, such disputes rumble on for years, with a noticeable impact on the farm, as people become disillusioned by the uncertainty.

Many title deeds were never updated after they were originally issued, and therefore they have no legal value; in other cases they are taken by relatives who want to gain access to the farm; in yet other instances they exist but people regard them as 'of no value; just a piece of paper', as they have failed to result in them obtaining loans. Nevertheless, title deeds carry important symbolic value; after all, they are what the 'purchase' areas were all about - the freedom to have the freehold, as this example illustrates:

There are some difficulties caused by our cousin who grabbed the farm's title deeds after my father's sister who was safekeeping the title deeds also died after the death of our father. We were too young to keep such important papers ... This disturbs our farming ... for example, in April we wanted to sell vegetables at OK supermarket, but they could not buy them because we failed to produce title deeds as proof of residence and made a great loss ... If our battle to get the title deeds succeeds we may be able to get a loan for drilling and installing boreholes and buying greenhouses.

\section{Cross-generational dynamics}

A key feature of our analysis has been change across generations. This has been far from predictable, with no uniform evolution of agricultural commercialization observed. Most farms had significant numbers of house structures; the average was nine, with the figure ranging from two to eighteen (see Figure 1). A number of these included investments by children, whose families sometimes were also resident, in order to keep links with 'home', even if working away was seen as important. As one informant recounted:

All my eight kids went to Gokomere after going to local primary near here. Some are working away, but my sons have homes here, and their wives and younger kids are around. It is a large extended family and my wife and my sons' wives work together. My eldest has a separate homestead and fields as part of the farm, but it is all part of the same community. We all work together.

By contrast, other farms are being abandoned owing to lack of interest by the younger generation. An eighty-one-year-old widow explained: 


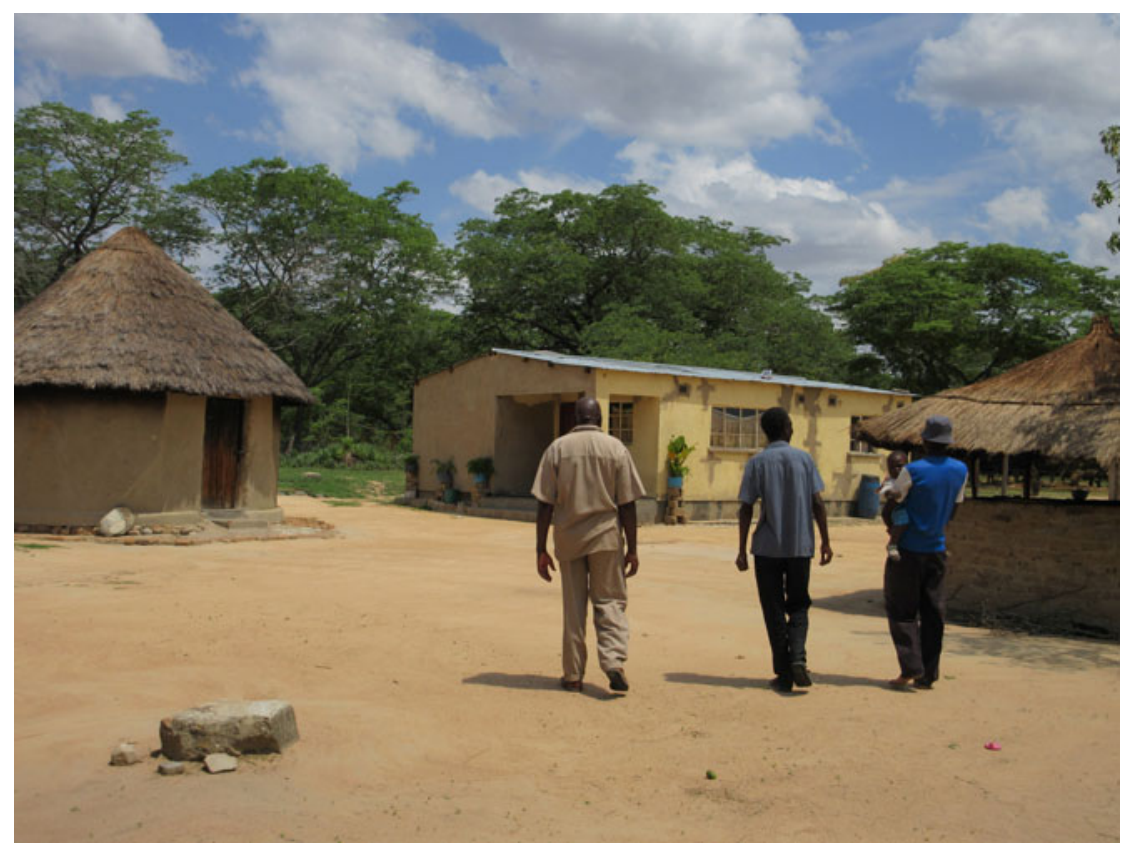

FIGURE 1 A 'villagized' farm in Mushagashe small-scale commercial farming area.

I am presently managing the farm, together with the second wife of my late husband. We are growing maize, cowpeas, groundnuts and finger millet. But we are facing a problem of low rainfall, and wild animals, like pig and spring hare. We have twenty-seven cattle, but our problem is distance to watering points. There is a drastic shortage of grass. I am hoping my son will come back and improve the farm, but he does not seem interested.

To get a sense of how cross-generational dynamics are evolving today, we explored the circumstances of the 109 living children of the sample household heads, 53 per cent of whom were female, across an age range from one to sixty-two. Twenty-four per cent were still in education, while 19 per cent of female children were living elsewhere following marriage. Of those with defined occupations $(n=72), 28$ per cent were in the civil service, with the importance of government jobs reflecting the pattern of their parents (Table 1). Many were teachers and workers in the health service, made possible by good educational qualifications; there were very few in the various security services compared with their parents, perhaps linked to the lack of connections with the current party state. As in the previous generation, the largest occupation category was defined as 'working in a company'. This varied hugely, from various highly skilled jobs overseas to relatively low-paid wage work in Zimbabwean firms. About a quarter defined themselves as self-employed; this was more common for women, mostly in their twenties and thirties. This again involved a diversity of work, often in the informal economy. Finally, 17 per cent defined themselves as 'farmers'. These were mostly older males, some of whom were farming in Mushagashe, while others had plots in 
communal and resettlement areas. Only a few had farms in the new resettlement areas, again reflecting the lack of social and political connections that were crucial during the land invasions in 2000. As one informant noted: 'The soil is tired here, no longer fertile. I regret not being able to join the land reform. We lost that chance.'

In terms of location, 14 per cent of the sample were resident on the farm, including the younger children and a few other sons and daughters who had settled there. The majority were living elsewhere in Zimbabwe, mostly in towns, but some farming in other rural areas. Twenty per cent were living outside Zimbabwe, mostly in countries abroad - including Australia, Canada, Ireland, South Africa, Sudan, the UK and the US. The educational head start that these children received, particularly when linked to mission education, for example at Gokomere, has ensured that most children born after independence have been able to secure good jobs. Quite a few are academics, but there are also doctors, lawyers and other professionals. Those educated in the first two decades after independence, now in their forties and fifties, are perhaps the most successful, while those younger than this have often had to struggle in a depressed local economy, and without the qualifications to get jobs abroad.

The fact that most children of current household heads are working away does not mean, however, that they are not interested in 'home' and the farm. As noted earlier, many send funds home to build houses and invest in projects of various sorts. Some men work away alone and have their wives and children at the farm, working closely with their parents, as part of an extended family unit. A big question for the future, though, is whether these educated, but dispersed, children will come back and farm, as their parents did a generation ago, resulting in a new burst of commercial activity at a time when the previous generation is ageing or passing on.

\section{Entrepreneurial projects}

A number of farms had ongoing 'projects', or at least plans for them. Many of these were linked to sons or daughters who were in employment but investing at home. Four had broiler projects (with an average flock size of seventy-six); two had pump irrigation for horticulture production; three had dairy operations; while others were investing in enterprises, including a beer hall and a major greenhouse project (see Figure 2). For example, one informant explained:

My uncle inherited the farm. He has recently retired as a plant engineer. He is still living in town but is planning to move back here soon. I live here, as my father is now late [has died], and help out. We mainly focus on maize production, getting six tonnes in good years. We grow beans, and some rice in the wetter portions of the field. The owner has been investing in some modern improvements to the farm. In addition to the new houses, a 50 metre deep borehole was drilled. Water is pumped into a 1,000 litre tank using a generator and irrigates a garden in addition to providing drinking water. A solar system is in place for lighting and playing the radio. We are planning another borehole in order to move into horticulture in a big way. We already started pen fattening of cattle; given limited grazing at this farm, pen fattening is the way to go. If capital becomes available we want to keep broilers and layers, and we are also thinking of fish farming, if we can increase our ponds. 


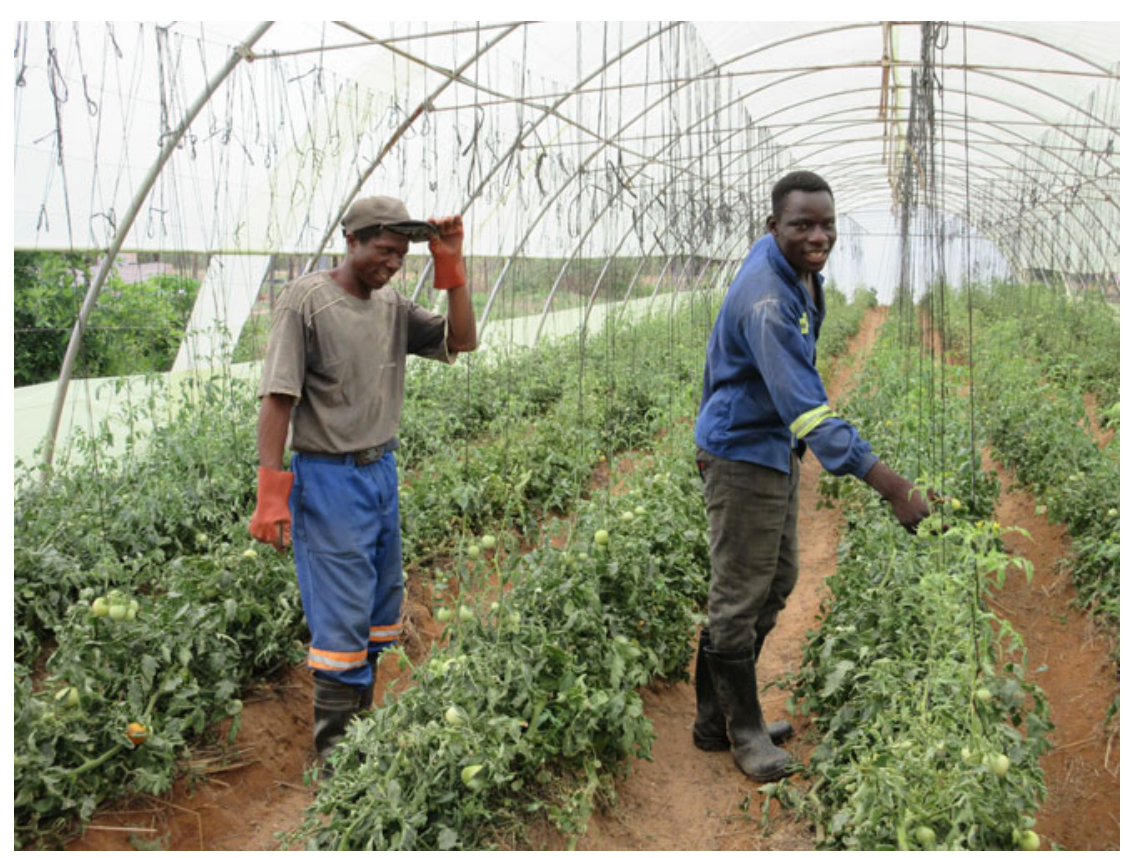

FIGURE 2 A new irrigated horticulture investment in Mushagashe.

Basic production challenges were often highlighted, but most informants had plans for diversification. For example:

Today there's continuous drought. I only use 2 hectares these days, and have one worker. Yields are poor and the GMB [Grain Marketing Board] don't pay. I have twelve cattle, and hold a few for others. I have one dairy cow, which I got on a loan, and sell milk to the Mushagashe dairy co-op. Two sons are staying here: one is resident, and he has a broiler project of a hundred birds, and has a separate home and field. I have an old truck, but it barely works. I need a borehole to do irrigation, but the cost is too much.

\section{The wider world}

Layered on top of these domestic and cross-generational dynamics are the impacts of external events and wider shocks. Across the interviews, the sense of abandonment by the state was evident: 'The government is not interested in us; it doesn't even come and repair the road.' Many complained about the lack of support, with the state failing to offer finance or markets, compounding other effects: 'Today production of crops and livestock is declining: the main cause being low rainfall and shortage of labour. There's a lack of finance to buy inputs and there are poor markets. All affect production.'

As several people pointed out, traditional leadership was prevented in the NPAs. 'We can't have politics here,' one commented. There are limited links to the ruling party, ZANU-PF, restricting patronage support. Such commentaries are combined with complaints about how, in earlier times, the state intervened 
too much, regulating farming practice. For example, destocking was mentioned as a major constraint on accumulation in the past: 'My father had a lot of cattle, but the white people forced him to reduce the number of cattle. The cattle were bought by the white man at a price that was pathetic; it was daylight robbery.'

In sum, periods of investment and accumulation are interspersed with periods of decline, and the pattern across households is far from uniform. A highly nonlinear and contingent pattern can be observed, affected by the intersection of local social relations and wider structural processes. With a few exceptions, the farms in our study are not exemplars of modernized commercial agriculture, as was hoped for, and they face many challenges. In the next section, based on our analysis of eighty years of Mushagashe SSCFA, we explore four pathways in more detail.

\section{Long-term pathways of change}

What, then, does our analysis suggest for medium-scale farming in the longerterm future? Eighty years ago the NPAs were seen as an opportunity for a new entrepreneurial class of farmers to emerge - these farmers were often highly educated, with jobs in the civil service or business and with close links to urban areas. As discussed above, the modernizing ambitions and the social profiles are very similar to those of medium-scale farmers across Africa today, including Zimbabwe's A2 farmers. Across the NPAs, and in Mushagashe in particular, we have seen that outcomes over time have not been predictable. They have been contingent on a range of factors, including both social dynamics across generations and genders, as well as structural political-economic drivers. Looking across our case studies, we can identify four main, but overlapping, pathways of change, ranging from idealized, but often temporary, commercial operations to farms that are effectively abandoned or simply held for the future.

\section{The commercial farm}

In this pathway, the regular sale of surplus production results in accumulation and reinvestment in the farm. This occurs through various forms of petty commodity production, but, as our data show, this much-hyped ideal may appear only sporadically as time-limited bursts of commercialization when conditions are right. For example, in the late 1950s and early 1960s, some farms in Mushagashe operated as serious commercial enterprises, supported by state policies on marketing, finance, infrastructure development, tenure security and so on. Their owners were resident, often retired, but not too old to run and manage a farm. But, in subsequent years, the commercial orientation faded, as older parents were no longer able to manage the farms and sons and other relatives were not around to reinvest. However, the economic crisis from the 1990s onwards meant that it became more attractive to abandon jobs in town, such as poorly paid civil service employment, in favour of farming, even if the family farm was remote and often run down by this stage. This has resulted in a renewed burst of activity. Commercial farming is thus something that happens at a certain life stage and is intimately linked to fortunes in the wider world of urban work, including patterns of income from remittances, now spread across an increasingly global diaspora. Political economy 
factors are crucial in both generating and closing down opportunities for commercialization. The structural adjustment period of the 1990s meant a decline in government services and investment in critical infrastructure such as roads. Redundancies and payouts at this time, however, allowed investment in farms. The economic crisis in the mid-2000s, and again today, has also increased the incentives to invest in farming, although under extremely difficult conditions and with limited external support.

\section{'Projectizing' the farm}

For those who are absent, and with parents or other relatives still alive and resident on the farm, the option of 'projectizing' the farm exists. Discrete projects are invested in, commonly involving livestock, especially dairy, piggeries and poultry. Sometimes these projects are loan-financed by development aid projects, such as the dairy project in which three in our sample were involved. More commonly they are self-financed by absent children, some in the diaspora. These investments need some management, and, if the parents are not capable of taking on the role, local people are employed as resident project managers. However, in Mushagashe, road and market infrastructure is poor due to years of state neglect, making any commercial project difficult. The projects in our sample just about break even, but are all backstopped by external finance. Projects also allow sons and daughters to have a stake in the family farm, but without committing to running it or living there. They provide a small supplement to keep now ageing parents in groceries, and allow school fees to be paid, for example, for some poorer relatives resident on the farm. Most importantly, such projects maintain a psychological link with 'home' and a sense of commitment and belonging, however limited. This, though, is far from the image of the commercial farm. It remains merely a collection of projects, with focused investments on limited land areas.

\section{The 'villagized' farm}

In this pathway, the land is viewed as belonging to a family, across generations. Over time, brothers, children and other relatives establish homes, and a village area is created. Sometimes these family units operate independently and have their own plots within the farm; in other cases they contribute collectively to what is usually the father's or elder brother's farm. Some members of these families may not be resident and may work elsewhere, but they regard the farm as 'home'. These villages - in the past viewed as 'squatter' settlements - may include others, such as labourers, or other relatives and their families, who are incorporated into the farm over time. Over the years, numbers can increase significantly. In our sample, one farm had nearly fifty people resident, including at least eight 'households' with plots plus several families of workers. In our survey, 38 per cent of farms had children's homes established on them, sometimes with a separate field. 


\section{Holding or abandoning the farm}

A final pathway is for farms to be left in the care of an elderly relative, who 'holds' the farm, with the prospect of a younger son returning at some point to take it on. Very limited activity is ongoing, and those living there are largely supported by flows of remittances. In the end, such farms may be abandoned on the death of those living there. Of the farms in our study area that were completely abandoned, we investigated the histories of three of them. In one, the owner had died around thirty years before. The sons live in the UK and Masvingo town and have plots in the new resettlements. Since the owner's death, local informants told us, no one had returned to the farm, which was now just used for grazing by neighbours. Another farm was inherited by a son who had never come to live there. He gradually sold all of his late parents' cattle and other farm equipment, leaving a worker to live there for years. Since then, the farm had been abandoned for a decade. In the third farm, the farm owner had died about twenty years earlier, leaving many cattle on the plot. No one had come to claim them, and they all disappeared over time. The place had been abandoned, but in recent years a female relative had arrived who is now spending intermittent periods of time on the farm, with plans to get it functioning again. Because of uncertainties about ownership, and the lack of incentives to sell, slow and more permanent abandonment can occur. This is perhaps becoming increasingly common as farm owners age and the younger generation is reluctant to commit to full-time farming.

Of these four highly contingent and non-linear pathways, the most common two among our sample of twenty-six were villagized and commercial farms (each at 35 per cent of cases). Nineteen per cent of farms could be characterized as 'projectized' (often combining with the above two categories), while 23 per cent of farms were being 'held', with real prospects of abandonment. The big question is what combination of these pathways is most likely to occur in other mediumscale farms across Africa, including Zimbabwe's A2 farms, after several generations.

\section{Conclusion}

There is nothing inevitable about pathways of agricultural commercialization. Looked at from the perspective of history, much depends on conjunctural factors (cf. Li 2014), including social dynamics (Berry 1993) as shaped by a wider political economy (Peters 2004). This contrasts with the standard depictions of agrarian change - whether from the perspective of structuralist Marxist analyses focusing on the competition between classes (cf. Bernstein 2010), or from the evolutionary approaches of agricultural or institutional economics that see a steady, path-dependent transformation of agrarian systems, based on the comparative value of key factors of production in a wider economy (cf. Mellor 1995). Instead, a nuanced, historical assessment of changing livelihoods over time suggests a much more complex story, with predictable changes (such as demographic shifts and ageing) confronting more uncertain events (whether ill health, mortality, drought or policy shifts). As Berry argues, 'no condition is permanent': 
Agricultural intensification has been neither inevitable nor continuous in African farming systems. In some areas, intensification was halted or reversed by changing environmental or political and economic conditions; in others, it has occurred not as an adaptive response to population growth or commercialization, but in the face of growing labour shortages and declining commercial activity. Such cases underscore the importance of studying farming as a dynamic social process. As farmers contend with social as well as environmental conditions, changes occur not only in what is produced and how much, but also in when work is done and by whom. (Berry 1993: 189)

What, then, does this imply for the future of medium-scale commercial farms in Africa? In Zimbabwe, the A2 farms are seen as potential drivers of commercial production, replacing the large-scale sector. While historical parallels are always limiting, and exact comparisons are not possible, there are some important questions that can be posed. While the NPAs were established under very different economic and political circumstances, and in places that were far from ideal in terms of agro-ecological conditions, infrastructural investment and marketing connections, there are important similarities of both policy ambition and composition of the farming population.

Our analysis shows four different but overlapping pathways of change emerging over eighty years. Singular, linear projections of agricultural commercialization are thus clearly inadequate. Commercialization emerges due to intersections of demographic cycles, changes in the wider economy, shifting environmental factors, external policy events, and more. The Mushagashe cases show how agriculture and agrarian change are always embedded in social and political relations and cannot be engineered through simple technocratic interventions and external policy - whether by allocating freehold tenure or by providing technical extension advice. Wider conditions of political economy are important too. In Mushagashe, state support for infrastructure investment (roads, water supply, dip tanks and markets) was significant in certain periods, allowing market connections to be made and the productivity of farming to increase, much as is suggested in the mainstream policy literature on agricultural commercialization (see, for example, Pingali and Rosegrant 1995; Wiggins et al. 2011). Equally, the state's actions have constrained livelihoods and opportunities for accumulation, whether through imposed restrictions on production (such as through destocking) or the limiting of political engagement, or by ignoring small-scale farming area populations during the land reform process. Conditions in the wider economy were crucial, too; these affected the supply of labour as well as opportunities for investment from remittances and off-farm work. In periods of economic crisis, as in the last decade, there have been increased demands for land, and farming has become an essential livelihood option.

There is no inevitability about such changes, however; instead, there are ebbs and flows, peaks and troughs, as fortunes change, conjunctures combine, and chance, luck and misfortune impinge. In the context of this non-linear, uncertain dynamic, a number of outcomes emerge: none are permanent, all are contingent on both local and wider conditions. Bursts of commercialization on farms are contingent on access to employment by farm holders, labour (hired, squatters and offspring), and, perhaps above all, money to invest. Some will achieve commercial success if the conditions are right; for others, this will be only temporary. For yet others, graduating to a significant commercial farm business may be out of 
reach, and the farm becomes something else - a home, a place of retirement, a source of security and independence - with farming combined with other livelihood activities. Policies can make a difference, but only up to a point. In eighty years' time, the four pathways seen in Mushagashe may emerge as typifying the potential outcomes seen in the medium-scale farms currently being established elsewhere across Africa. This article therefore suggests a more qualified response to the current hype about policies to encourage commercialization pathways and medium-scale farms in Africa.

\section{Acknowledgements}

We would like to thank the farmers of Mushagashe for participating in the research and local Agritex officers in Masvingo for continuing to support our work. This study was undertaken as part of ongoing research on land reform in Zimbabwe $(<\mathrm{http}: / /$ www.zimbabweland.net>), in part supported by the ESRC STEPS Centre (ES/I021620/1), and contributes to work under the DFID-funded Agricultural Policy Research in Africa (APRA) programme of the Future Agricultures Consortium (<http://www.future-agricultures. org >). Tragically, B. Z. Mavedzenge passed away before this article was finalized, but he was a major contributor to this study and our wider research.

\section{References}

Anseeuw, W., T. Jayne, R. Kachule and J. Kotsopoulos (2016) 'The quiet rise of medium-scale farms in Malawi', Land 5 (3): 19.

Ashworth, V. A. (1994) Towards Sustainable Smallholder Agriculture: a survey of the small-scale commercial farm sector. Harare: World Bank, Ministry of Lands, Agriculture and Water Development.

Bernstein, H. (1998) 'Social change in the South African countryside? Land and production, poverty and power', Journal of Peasant Studies 25 (4): 1-32.

Bernstein, H. (2010) Class Dynamics of Agrarian Change. Halifax, Nova Scotia: Fernwood Press.

Berry, S. (1989) 'Access, control and use of resources in African agriculture: an introduction', Africa 59 (1): 1-5.

Berry, S. (1993) No Condition Is Permanent: the social dynamics of agrarian change in sub-Saharan Africa. Madison WI: University of Wisconsin Press.

Boone, C. (2007) 'Property and constitutional order: land tenure reform and the future of the African state', African Affairs 106 (425): 557-86.

Cheater, A. (1981) 'Women and their participation in commercial agricultural production: the case of medium-scale freehold in Zimbabwe', Development and Change 12 (3): 349-77.

Cheater, A. P. (1982) 'Formal and informal rights to land in Zimbabwe's black freehold areas: a case-study from Msengezi', Africa 52 (3): 77-91.

Cheater, A. P. (1984) Idioms of Accumulation: rural development and class formation among freeholders in Zimbabwe. Gweru: Mambo Press.

Collier, P. and S. Dercon (2014) 'African agriculture in 50 years: smallholders in a rapidly changing world?', World Development 63: 92-101. 
Cousins, B. and I. Scoones (2010) 'Contested paradigms of "viability" in redistributive land reform: perspectives from southern Africa', Journal of Peasant Studies 37 (1): 31-66.

Dancer, H. and D. Tsikata (2015) 'Researching commercial agriculture in subSaharan Africa with a gender perspective: concepts, issues and methods'. Future Agricultures Consortium Working Paper 132. Brighton: Future Agricultures Consortium, Institute of Development Studies, University of Sussex.

Jayne, T. S., A. Chapoto, N. Sitko, C. Nkonde, M. Muyanga and J. Chamberlin (2014) 'Is the scramble for land in Africa foreclosing a smallholder agricultural expansion strategy?', Journal of International Affairs 67 (2): 35-53.

Jayne, T. S., J. Chamberlin, L. Traub, N. Sitko, M. Muyanga, F. K. Yeboah, W. Anseeuw, A. Chapoto, A. Wineman, C. Nkonde and R. Kachule (2016) 'Africa's changing farm size distribution patterns: the rise of medium-scale farms', Agricultural Economics 47 (S1): 197-214.

Li, T. M. (2014) Land's End: capitalist relations on an indigenous frontier. Durham NC: Duke University Press.

Makuvaro, V., C. T. Murewi, J. Dimes and I. Chagonda (2017) 'Are smallholder farmers' perceptions of climate variability and change supported by climate records? A case study of Lower Gweru in semiarid central Zimbabwe', Weather, Climate, and Society 10 (1): 35-49.

Mapfumo, P., F. Mtambanengwe and B. Vanlauwe (2007) 'Organic matter quality and management effects on enrichment of soil organic matter fractions in contrasting soils in Zimbabwe', Plant and Soil 296 (1-2): 137-50.

Mellor, J. W. (1995) Agriculture on the Road to Industrialization. Baltimore MD: Johns Hopkins University Press for the International Food Policy Research Institute.

Morris, M. L., H. P. Binswanger-Mikhize and D. Byerlee (2009) Awakening Africa's Sleeping Giant: prospects for commercial agriculture in the Guinea Savannah Zone and beyond. Washington DC: World Bank Publications.

Moyo, S. (2011) 'Three decades of agrarian reform in Zimbabwe', Journal of Peasant Studies 38 (3): 493-531.

Moyo, S. and W. Chambati (eds) (2013) Land and Agrarian Reform in Zimbabwe: beyond white-settler capitalism. Dakar: CODESRIA.

Mujere, J. (2014) 'Evangelists, migrants and progressive farmers: Basotho as "progressive Africans" in Southern Rhodesia, 1890-1927', Journal of Southern African Studies 40 (2): 295-307.

Palmer, R. H. (1977) Land and Racial Domination in Rhodesia. London: Heinemann.

Peters, P. E. (2004) 'Inequality and social conflict over land in Africa', Journal of Agrarian Change 4 (3): 269-314.

Phimister, I. (1988) An Economic and Social History of Zimbabwe, 1890-1948: capital accumulation and class struggle. London: Longman.

Pingali, P. and M. Rosegrant (1995) 'Agricultural commercialization and diversification: processes and policies', Food Policy 20 (3): 171-85.

Potts, D. (2010) Circular Migration in Zimbabwe and Contemporary Sub-Saharan Africa. Woodbridge: Boydell and Brewer. 
Poulton, C., J. Kydd and A. Dorward (2006) 'Overcoming market constraints on pro-poor agricultural growth in sub-Saharan Africa', Development Policy Review 24 (3): 243-77.

Ranger, T. O. (1985) Peasant Consciousness and Guerrilla War in Zimbabwe: a comparative study. Oxford: James Currey.

Ranger, T. O. (1995) Are We Not Also Men? The Samkange family and African politics in Zimbabwe, 1920-64. Oxford: James Currey.

Scoones, I. (2015) 'Zimbabwe's land reform: new political dynamics in the countryside', Review of African Political Economy 42 (144): 190-205.

Scoones, I., N. Marongwe, B. Mavedzenge, J. Mahenehene, F. Murimbarimba and C. Sukume (2010) Zimbabwe's Land Reform: myths and realities. Woodbridge: James Currey.

Shutt, A. K. (1997) 'Purchase area farmers and the middle class of southern Rhodesia, c.1931-1952', International Journal of African Historical Studies 30 (3): 555-81.

Shutt, A. K. (2000) 'Pioneer farmers and family dynasties in Marirangwe purchase area, colonial Zimbabwe, 1931-1947', African Studies Review 43 (3): 59-80.

Shutt, A. K. (2002a) 'Squatters, land sales and intensification in Marirangwe purchase area, colonial Zimbabwe, 1931-65', Journal of African History 43 (3): 473-98.

Shutt, A. K. (2002b) 'The settlers' cattle complex: the etiquette of culling cattle in colonial Zimbabwe, 1938', Journal of African History 43 (2): 263-86.

Sitko, N. J. and T. S. Jayne (2014) 'Structural transformation or elite land capture? The growth of "emergent" farmers in Zambia', Food Policy 48: 194-202.

van der Ploeg, J. D. (2013) Peasants and the Art of Farming: a Chayanovian manifesto. Halifax, Nova Scotia: Fernwood Press.

West, M. O. (2002) The Rise of an African Middle Class: colonial Zimbabwe, 1898-1965. Bloomington IN: Indiana University Press.

White, B. (2012) 'Agriculture and the generation problem: rural youth, employment and the future of farming', IDS Bulletin 43 (6): 9-19.

Wiggins, S., G. Argwings-Kodhek, J. Leavy and C. Poulton (2011) 'Small farm commercialisation in Africa: reviewing the issues'. Future Agricultures Consortium Research Paper 23. Brighton: Future Agricultures Consortium, Institute of Development Studies, University of Sussex.

Wolmer, W. and I. Scoones (2000) 'The science of "civilized" agriculture: the mixed farming discourse in Zimbabwe', African Affairs 99 (397): 575-600.

\begin{abstract}
Across Africa there has been a growth in medium-sized farms, including in Zimbabwe following the land reform of 2000. What are the prospects of such farms driving new forms of agricultural commercialization? In this article we seek to learn lessons from the past by examining the experience of "native purchase areas', which were established from the 1930s in Zimbabwe. Through a detailed historical study of Mushagashe small-scale commercial farming area in Masvingo Province, the article explores the changing fortunes of farms over time. Historical information is complemented by a survey of twenty-six randomly selected farms, examining patterns of production, asset ownership and
\end{abstract}


accumulation. In-depth interviews explore life histories and changes in social arrangements that have influenced agrarian change. Four broad farm types are identified, including those that are commercialized, projectized, villagized, and held or abandoned. These categories are not static, however, and the article emphasizes non-linear patterns of change. Following Sara Berry, we show how pathways of commercialization are diverse and unpredictable, influenced by interlocking conjunctures of social dynamics, generational changes and political-economic conditions. Commercialization outcomes are dependent on the intersection of relational dynamics and more structural, political economy factors. Bursts of commercialization on these farms are contingent on access to employment by farm owners, labour (hired, squatters and offspring) and, perhaps above all, money to invest. The much-hyped policy vision of a new medium-scale commercial farm sector emerging in Africa therefore must be qualified, and divergent outcomes recognized.

\section{Résumé}

Partout en Afrique, le nombre d'exploitations agricoles de taille moyenne a augmenté, y compris au Zimbabwe après la réforme agraire de 2000. Ces exploitations ont-elles des chances de stimuler de nouvelles formes de commercialisation agricole ? Dans cet article, les auteurs cherchent à tirer les enseignements du passé en examinant l'expérience des « native purchase areas » [zones réservées à l'accession à la propriété des indigènes] qui furent créées à partir des années 1930 au Zimbabwe. À travers une étude historique détaillée de la région de Mushagashe dans la province de Masvingo, l'article explore les vicissitudes des exploitations agricoles au fil du temps. Ces données historiques sont complétées par une étude portant sur vingt-six exploitations choisies de façon aléatoire qui examine les schémas de production ainsi que la propriété et l'accumulation d'actifs. Des entretiens approfondis explorent des récits de vie et les changements d'organisation sociale qui ont influencé le changement agraire. Quatre grands types d'exploitations sont identifiés, y compris les exploitations commercialisées, projetisées, villagisées, et conservées ou abandonnées. Ces catégories ne sont cependant pas statiques et l'article souligne la non-linéarité des schémas d'évolution. Suivant Sara Berry, les auteurs montrent la diversité et le caractère imprévisible des trajectoires de commercialisation influencés par des conjonctures imbriquées de dynamique sociale, de changements générationnels et de conditions politicoéconomiques. Les résultats de commercialisation dépendent de l'intersection de dynamiques relationnelles et de facteurs économiques et politiques plus structurels. Les poussées de commercialisation sur ces exploitations sont subordonnées à l'accès à l'emploi par les chefs d'exploitation, à la maind'œuvre (salariée, squatteurs et progéniture) et peut-être surtout aux moyens financiers pour investir. Il convient donc de qualifier la vision d'orientation, exagérément vantée, d'un nouveau secteur agricole commercial à moyenne échelle émergent en Afrique, et de reconnaître la divergence de résultats. 